\title{
Limbus Vertebra Mimicking Avulsion Fracture
}

\author{
Avülsiyon Fraktürünü Taklit Eden Limbus Vertebra
}

(1) Senem Şaş

Ahi Evran University Training and Research Hospital, Clinic of Physical Medicine and Rehabilitation, Kırşehir, Turkey

\begin{abstract}
Limbus vertebra (LV) is a lesion formed by uniform triangular bone fragment through marginal interosseous herniation of the nucleus pulposus or adjacent bone affecting the margin angle of vertebral bodies. It is usually seen in radiographs incidentally. LV can be misdiagnosed as vertebral fracture, Schmorl node, infection or tumor. In this paper, we present a 69-year-old woman who was admitted to our outpatient clinic with the complaint of mechanical low back pain and was diagnosed with anterior LV and intervertebral disc degeneration.
\end{abstract}

Keywords: Limbus vertebra, interosseous herniation, disc degeneration, fracture

\section{Öz}

Limbus vertebra (LV), nukleus pulposusun marjinal interosseöz herniasyonu veya vertebra cisimlerinin kenar açısını etkileyen komşu kemik nedeniyle uniform üçgen kemik parçası ile karakterize lezyondur. Genellikle grafilerde rastlantısal olarak görülür. Fakat LV vertebra kırığı, Schmorl nodülü, enfeksiyon veya tümör ile karıştırılabilir. Bu yazıda, mekanik bel ağrısı şikayetiyle polikliniğimize başvuran ve anterior LV ve intervertebral disk dejenerasyonu tanısı konan 69 yaşındaki bir kadın sunulmuştur.

Anahtar Sözcükler: Limbus vertebra, interosseöz herniasyon, disk dejenerasyonu, kırık

\section{Introduction}

Limbus vertebra (LV) is a bone structure formed by uniform triangular bone fragment. This condition occurs through marginal interosseous herniation of the nucleus pulposus or vertebra. LV affects the margin angle of the vertebral bodies. The herniation is formed in childhood or adolescence (1). The differential diagnosis of LV includes vertebral fracture, infection, Schmorl node or tumor. Mechanical low back pain is typical rather than inflammatory low back pain. Clinical signs also include back pain and, motor deficit can also be seen (2). Several papers described an association between LV and low back pain (3-8). This condition may be through intervertebral disc degeneration (3-5). In this report, we present a-69-year-old woman with LV who presented with the complaint of chronic low back pain and was misdiagnosed as vertebral fracture.

\section{Case}

A 69-year-old woman was admitted to our hospital with the complaint of chronic low back pain and back pain radiating into the buttocks. There were no clinical signs of morning stiffness, weight loss, fever or inflammatory pain. She had neuropathic pain. There was no history of trauma, smoking and alcohol. She was using warfarin for mitral valve replacement. There was antalgic gait. Lumbar range of motion was limited in end-range flexion, extension and neutral postures. Neurological examination was normal. It was observed that thoracic kyphosis was increased. Lumbosacral magnetic resonance imaging (MRI) revealed disk protrusion at L3-4 and L5-S1 levels and neural foraminal narrowing and avulsion fracture of L4 (Figure 1-3). Anterior LV at L4 and intervertebral disc degeneration were observed. Bone mineral density measurement revealed osteopenia. Based on the clinical and radiological findings, the patient was diagnosed with lumbar disc degeneration and anterior LV. The patient was prescribed pregabalin $150 \mathrm{mg} /$ day for neuropathic pain and $1000 \mathrm{mg}$ calcium and $1200 \mathrm{IU}$ vitamin D for osteopenia. Posture, spinal extension and low back, back and hip stretching exercises were recommended..
Address for Correspondence/Yazışma Adresi: Senem Şaş

Ahi Evran University Training and Research Hospital, Clinic of Physical Medicine and Rehabilitation, Kırşehir, Turkey

Phone: +90 38621345 15/1169 E-mail: senemsas@gmail.com ORCID ID: orcid.org/0000-0002-5616-5723 Received/Geliş Tarihi: 02 February 2018 Accepted/Kabul Tarihi: 08 April 2018
${ }^{\circ}$ Copyright 2019 by The Medical Bulletin of University of Health Sciences Haseki Training and Research Hospital

The Medical Bulletin of Haseki published by Galenos Yayınevi.

${ }^{8}$ Telif Hakkı 2019 Sağlık Bilimleri Üniversitesi Haseki Eğitim ve Araştırma Hastanesi Haseki Tıp Bülteni, Galenos Yayınevi tarafından yayınlanmıştır. 


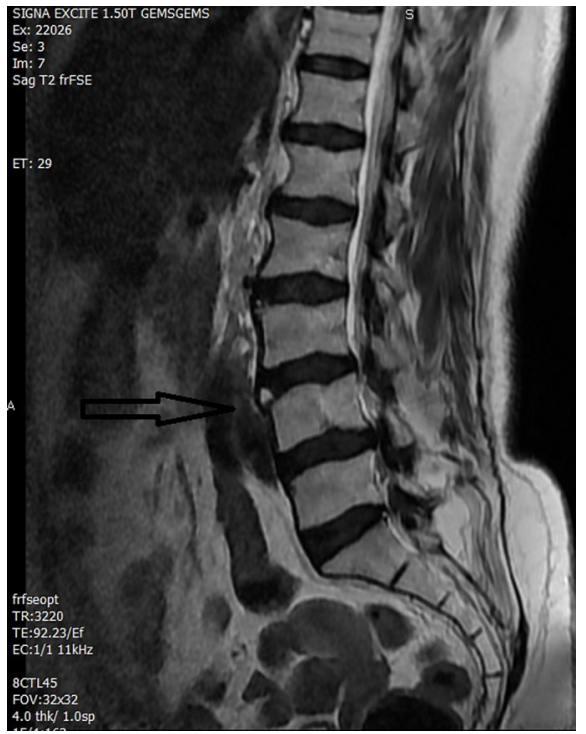

Figure 1. Limbus vertebra at L4 level

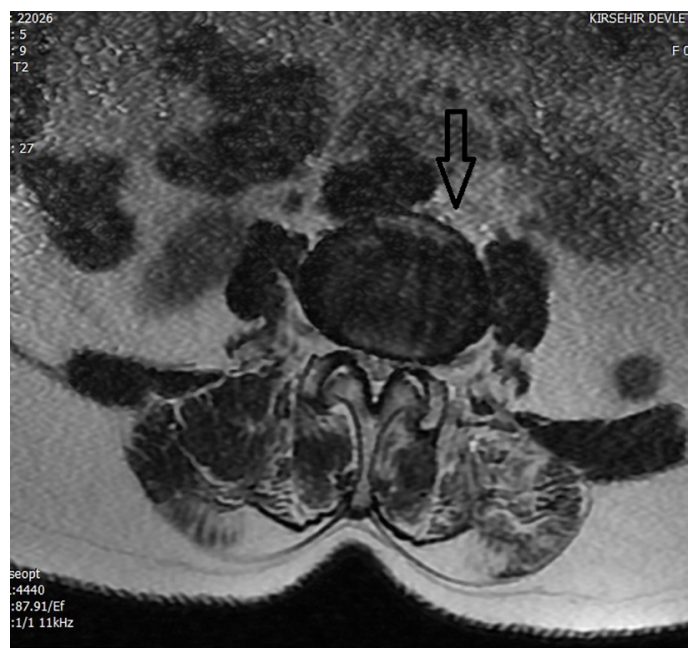

Figure 2. Limbus vertebra on axial projection

\section{Discussion}

LV was first described in 1927. LV occurs secondary to trauma in immature skeleton during childhood or adolescence. LV is caused by an intrabody marginal herniation of the nucleus pulposus leading to the separation of a triangular bone fragment (2). The pathogenesis of LV is related to Scheuermann's disease (6). The diagnosis is made with plain lateral radiograph showing a detached fragment with triangular morphology and sclerotic margins. The most affected region is superior anterior corner of the vertebra and the other regions are less frequently involved (1).

Genetics and biomechanical loading especially during back flexion may be important in developing LV. Bennett

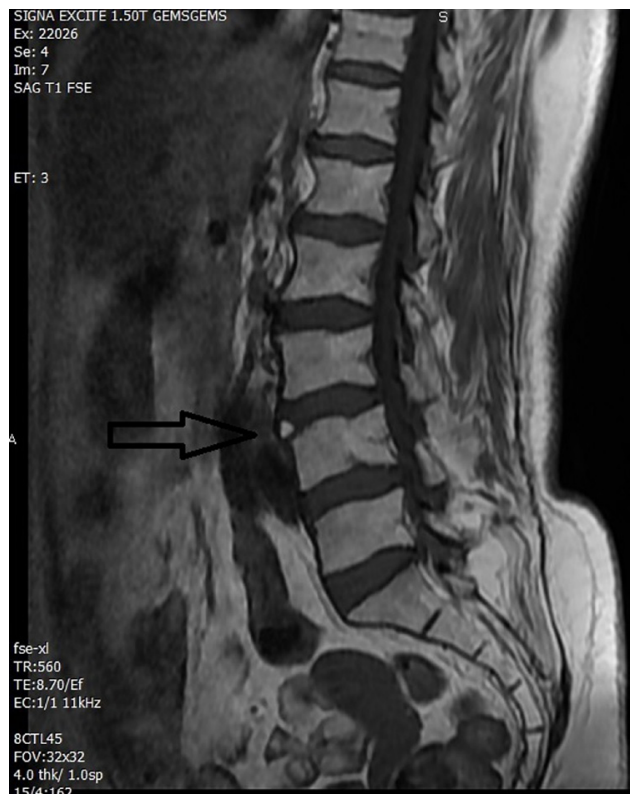

Figure 3. Limbus vertebra in T1 weighted-sequence

et al. (7) reported the risk of LV by gene encoding at the a1 chain of type XI collagen by a TT genotype of COL11A1 polymorphism.

Some researchers suggest that LV is an incidental finding. However, there is an increasing interest on anterior LV. Posterior LV precipitates lumbar spinal stenosis (8). In this report, the patient was considered having asymptomatic $\mathrm{LV}$, since the pain linked with disc degeneration.

LV can be misdiagnosed as vertebral fracture, tumor, infection or Schmorl node. LV is herniation of the margin whereas Schmorl node is a more central herniation into the vertebral plate (2). LV is superimposed with pelvic structures especially at the L5-S1 segment. Therefore, the diagnosis of LV must be confirmed with MRI (9). The diagnostic method in our case was MRI.

In their study including 104 Japanese collegiate gymnasts, Koyama et al. (3) reported that anterior LV was a significant predictor of the development of intervertebral disc degeneration. It has been reported that presence of anterior LV at early age can trigger intervertebral disc degeneration (4). It has been reported that intervertebral disc degeneration was accelerated in extruded disc in patients with LV (5).

LV has not a specific symptom, so that it is generally detected incidentally. There are a limited number of reported cases in the literature. Tuna et al. (10) reported a 29-yearold woman with anterior LV mimicking inflammatory back pain. In their paper, Mutlu ve Ogul (11) reported a case of cervical LV presenting as a hypopharyngeal mass. In this report, we present a case of anterior LV mimicking avulsion fracture. 
In general, LV requires no treatment. Symptomatic patients are managed conservatively. In case of posterior LV with associated nerve root compression, surgical decompression may be needed (12). Surgery may also be considered when conservative treatment fails. Total laminectomy is recommended for successful excision of posterior LV (9). It has been also recommended excision of the LV (13).

In conclusion, LV is a radiological finding and its prevalence and importance are unknown. The present case can explain the association of LV with intervertebral disc degeneration. LV is usually mistaken for vertebral fractures. LV is an incidental radiological finding rather than a specific condition. Awareness of LV protects patients from unnecessary treatment procedures.

Financial Disclosure: The authors declared that this study received no financial support.

\section{References}

1. Sanal HT, Yilmaz S, Simsek I. Limbus vertebra. Arthritis Rheum 2012;64:4011.

2. Ghelman B, Freiberger RH. The limbus vertebra: an anterior disc herniation demonstrated by discography. AJR Am J Roentgenol 1976;127:854-5.

3. Koyama K, Nakazato K, Min SK, et al. Anterior limbus vertebra and intervertebral disk degeneration in japanese collegiate gymnasts. Orthop J Sports Med 2013;1:2325967113500222.
4. Wang $Y$, Videman T, Battié MC. Lumbar vertebral endplate lesions: prevalence, classification and association with age. Spine (Phila Pa 1976) 2012;37:1432-9.

5. Hsu K, Zucherman J, Shea W, et al. High lumbar disc degeneration. Incidence and etiology. Spine (Phila Pa 1976) 1990;15:679-82.

6. Hollingworth $\mathrm{P}$. Back pain in children. $\mathrm{Br} J$ Rheumatol 1996;35:1022-8.

7. Bennett $D L$, Nassar L, DeLano MC. Lumbar spine MRI in the elite-level female gymnast with low back pain. Skeletal Radiol 2006;35:503-9.

8. Goldman AB, Ghelman B, Doherty J. Posterior limbus vertebrae: a cause of radiating back pain in adolescents and young adults. Skeletal Radiol 1990;19:501-7.

9. Huang PY, Yeh LR, Tzeng WS, et al. Imaging features of posterior limbus vertebrae. Clin Imaging 2012;36:797-802.

10. Tuna S, Ozdemir T, Oz HE. Journal of Clinical and Diagnostic Research. 2016 Mar, Vol-10(3): YD01-YD02.

11. Mutlu V, Ogul H. Cervical limbus vertebra presenting as a hypopharyngeal mass. The Spine Journal 2014;14:1079-80.

12. Sanal HT, Yilmaz S, Simsek I. Limbus vertebra. Arthritis Rheum 2012;64:4011.

13. Akhaddar A, Belfquih H, Oukabli M, Boucetta M. Posterior ring apophysis separation combined with lumbar disc herniation in adults: a 10-year experience in the surgical management of 87 cases. J Neurosurg Spine 2011;14:475-83. 